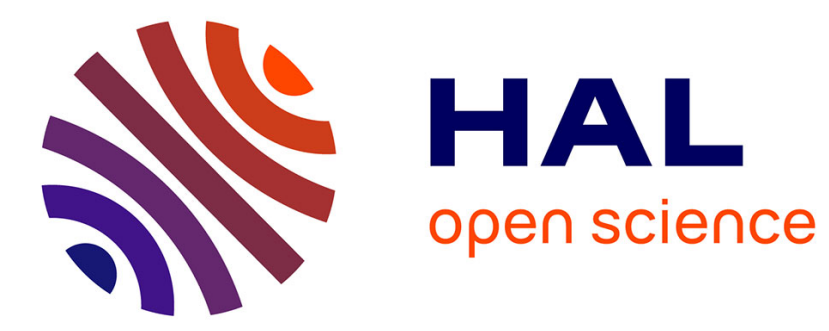

\title{
Expectations, information, and migration: the case of the West Bank and Gaza
}

\author{
Stuart A Gabriel, Daniel Levy
}

\section{To cite this version:}

Stuart A Gabriel, Daniel Levy. Expectations, information, and migration: the case of the West Bank and Gaza. Applied Economics, 1988, 20 (1), pp.1-13. 10.1080/00036848800000032 . hal-02382418

\section{HAL Id: hal-02382418 \\ https://hal.science/hal-02382418}

Submitted on 27 Nov 2019

HAL is a multi-disciplinary open access archive for the deposit and dissemination of scientific research documents, whether they are published or not. The documents may come from teaching and research institutions in France or abroad, or from public or private research centers.
L'archive ouverte pluridisciplinaire HAL, est destinée au dépôt et à la diffusion de documents scientifiques de niveau recherche, publiés ou non, émanant des établissements d'enseignement et de recherche français ou étrangers, des laboratoires publics ou privés. 


\title{
Expectations, Information, and Migration: The Case of the West Bank and Gaza*
}

\author{
Stuart A. Gabriel \\ Division of Research and Statistics \\ Board of Governors of the Federal Reserve System, \\ washington, DC, USA \\ Daniel Levy \\ Department of Economics \\ University of Minnesota \\ Minneapolis, MN, USA
}

\begin{abstract}
This study evaluates the determinants of Palestinian migration from the West Bank and Gaza. Data are employed for the post-1967 period of Israeli rule to specify and test competing models as well as the structure of expectations in the migration decision. Results of the analysis support a simple static expectation formulation, as is consistent with much of the shortterm, low mobility cost migration between the West Bank and Jordan. Findings further point to the importance of various Israeli-Palestinian economic and political economic interactions in the determination of this controversial movement of population, including those associated with employment opportunity for Palestinian labor in Israel, elements of Israeli West Bank settlement policy and changes in local standard of living. Various policy implications of the research are indicated.
\end{abstract}

* The authors wish to acknowledge a computing grant from the University of Minnesota Computer Center. We are further grateful to Thomas Rothenberg, Christopher Sims, Mark Rosenzweig, Norman Simler, Emanual Barnea, Lung-Fei Lee, Baruch Mevorach and an anonymous referee for helpful comments. 


\section{Introduction}

Population change in the West Bank and Gaza has roused considerable political controversy. ${ }^{1}$ Israeli policy has sought to redress the 'demographic imbalance' in these areas, through the establishment of numerous urban settlements and the encouragement of sizable Jewish in-migration. In contrast, Arab and Palestinian groups promote the 'steadfastness' of the indigenous population, this in the wake of large scale emigration. The USA has recently put pressure on Israel over the use of economic aid for employment development in the territories, so as to ease pressure on Palestinians to emigrate. ${ }^{2}$ All parties view the magnitude and determinants of those migratory flows with particular concern, given their implications for control of territory and conflict resolution.

This study seeks to evaluate the determinants of Palestinian migration from the West Bank and Gaza. The research employs data for the post-1967 period of Israeli rule which enable specification and testing of certain economic and political economic theories of migration. In particular, the analysis evaluates competing model formulations as well as the structure of expectations in the migration decision.

In that regard, discussion is initiated in Section II with a brief overview of Palestinian emigration from the territories. In Section III, an econometric model is specified which incorporates various expectations formulations of migration

\footnotetext{
1 The West Bank includes the area between the Jordan River and the 1949 Armistice line between the Kingdom of Jordan and the State of Israel. The Gaza Strip was created as a separate administrative unit as a result of the Armistice Agreement between Egypt and Israel in 1949. It includes the area between the Mediterranean Sea, those armistice lines to the north and east, and the international border between Egypt and Israel to the south.

2 US Secretary of State, George Schultz, is reported to have pressed Israel for a change in the policy that limits the use of US economic aid to Arabs of the West Bank and Gaza to public works. See Newsweek, 18 June 1984, p. 21.
} 
economic return. Section IV then provides evaluation of static, extrapolative and adaptive expectations variants of the model, indicating their differential relevance to the west Bank and Gaza Strip samples.

Results of the analysis in general support a simple static expectations formulation, as is consistent with much of the short-term, low mobility cost migration between the West Bank and Jordan. Findings further point to the importance of various Israeli-Palestinian political economic interactions in the determination of this controversial movement of population, including those associated with employment opportunity for Palestinian labor in Israel, elements of Israeli West Bank settlement policy and changes in local standard of living. Finally, on the basis of these analyses, Section $V$ provides various policy recommendations and conclusions.

\section{Migration from the West Bank and Gaza}

Arab emigration from the west Bank dates to hostilities associated with the 1947 partition of Palestine and the subsequent annexation of this area by Transjordan. During the twenty-year period of Jordanian rule, until June 1967, approximately 400000 West Bank inhabitants crossed the Jordan River to the East Bank (Nisan, 1982, p. 195). The move involved short distances within an area of cultural, religious, linguistic and administrative uniformity. It was not a forced migration but reflected rather the East Bank orientation of Jordanian development policy, in which investment, political and educational activities were centered in the Amman-Zurqa zone.

Prior to Jordanian annexation of the West Bank, this area was far more developed than the East Bank, due to economic 
spillovers from the proximate British and Jewish sectors. These spillovers ceased with the closing of borders during the 1948 war. While the 1952 West Bank population of 742000 well exceeded the 587 $00 \odot$ East Bank inhabitants, subsequent Jordanian industrialization and agricultural development of the East Bank succeeded in reversing the relative weight of these areas. By 1961, the West Bank population was 801000 , while that of the East Bank was estimated at 879 0๑๑.3 On the eve of the 1967 war, the latter's population exceeded one million, while the west Bank population remained static at about 800000 (Nisan, 1982, p. 195 ).

During and immediately after the 1967 war, about 200000 West Bank inhabitants crossed the Jordan River to the East Bank (Ben Shahar et al., 1971, p. 29). Not all remained there; some pursued economic opportunities in the Persian Gulf, North America and elsewhere. The sizable emigration of Palestinians from the West Bank was not unique to Jordanian rule, however, and has continued during the Israeli administration of the territories.

Evaluation of economic conditions in the Gaza Strip over the same period indicates policy neglect and structural underdevelopment. In that regard, per capita GNP amounted to 27 dinars in 1966, approximately half that of the West Bank, and among the lowest in the world (Ben Shahar et al., 1971, p. 29). While Egyptian development efforts similarly favored other regions, substantial educational advances were made due primarily to the efforts of UNRWA and other philanthropic organizations. Poverty and limited local employment opportunities precipitated similar emigration from this region.

\footnotetext{
3 A relative preponderance of woman in the West Bank population emerged during this period, the ratio of men to women in the 15-19 and 30-44 age groups amounting to 0.84 and 0.75 , respectively.
} 
Post-1967 Palestinian migration from the West Bank and Gaza is depicted in Fig. 1. Subsequent to the massive emigration of refugees in 1967, yearly average emigration from those areas up to 1973 remained at the relatively low rates of 4.4 and 6.8 per thousand, respectively. In each region, annual emigration was below the 10000 person level. Subsequent to 1974, however, migration rates from the territories registered a substantial increase and in the West Bank have averaged about 19 per thousand or 14000 per year through 1982. In Gaza a similar trend is illustrated, yet its magnitude is approximately half that of the west Bank.

While no direct information exists regarding the demographic characteristics of the migrants, evaluation of the age/sex composition of the remaining population indicates that the proportion of the 25-44 age group in the population aged over 15 is lower than the proportion of this group in Israel, among both Jews and non-Jews. Further, there are substantially fewer men than women in this age group. According to information derived from labor force surveys, $90 \%$ of those abroad are men, $60 \%$ of whom left the country in search of employment, primarily those in the 18-24 group (Meron, 1983, p. 36). 


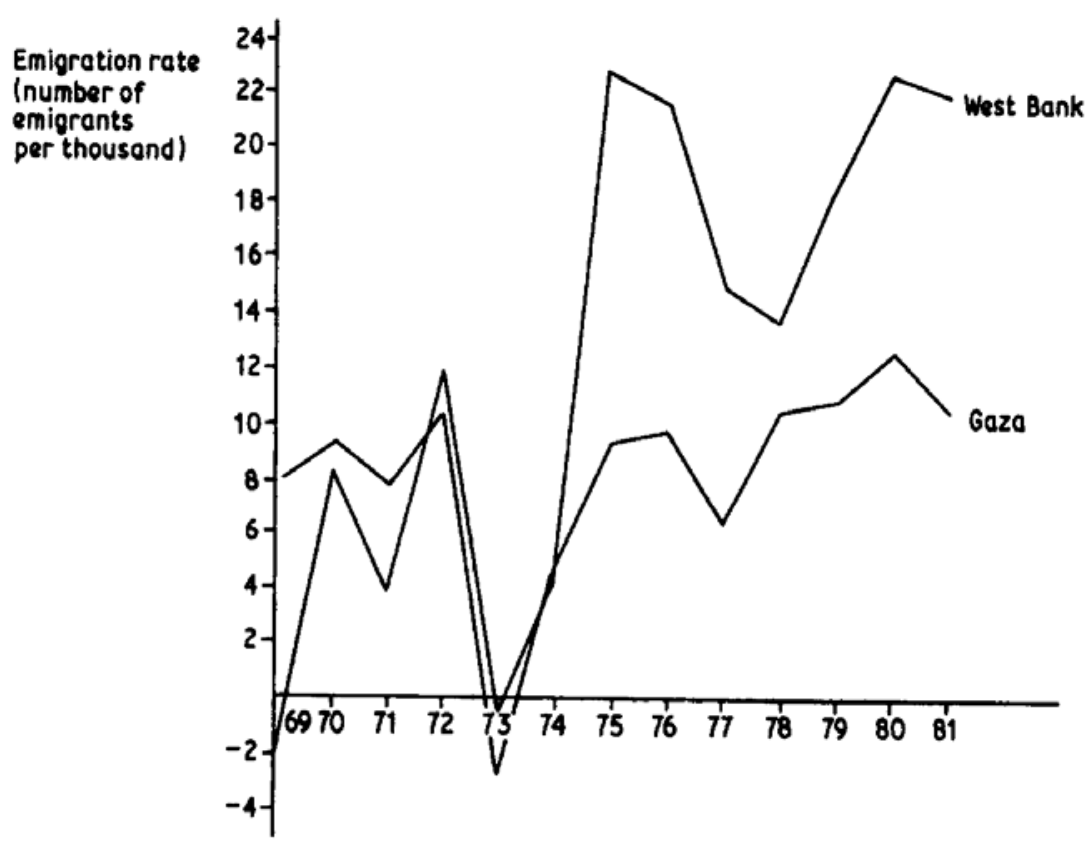

Figure 1

These trends indicate a low population growth in the west Bank, in which a high rate of natural increase is for the most part offset by the sizable and negative migration balance. In 1980, for instance, 83\% of the natural increase of about 20000 was countered by emigration (Benvenisti, 1982, p. 1). Emigration, coupled with high mortality rates, yields an average annual growth rate of the West Bank population between 1968 and 1980 of $1.4 \%$. The annual growth rates of the Jewish and nonJewish populations in Israel during the same period were 2.53 and 3.39\%, respectively (Benvenisti, 1982, p. 1).

Various Palestinian-Israeli political economic interactions impinge on the migratory phenomenon. The territories export substantial labor services to Israel, accounting for 27 and 33\% of the West Bank and Gaza labor forces, on average, over the 1970-81 period (Statistical Abstract of Israel, 1982, ch. 27, 
table 22). In 1974, earnings from such employment comprised over one-quarter of West Bank GNP, their multiplier effect accounting for one-half the growth in incremental GNP over the 1968-73 period (Sandler and Frisch, 1981, p. 135). Concomitant growth in real, per capita consumption was substantial, averaging $6.7 \%$ in the West Bank and 6.4\% in Gaza between 1968 and 1981. Private consumption accounted for $72 \%$ of domestic uses in the economies of the territories, significantly higher than the 54 to $59 \%$ recorded for Israel, Jordan, Egypt and Syria (Meron, 1983, p. $15)$.

During the mid-1970s a rise in residential construction occurred in the territories, precipitated in part by savings accumulated by residents over earlier years. The scale of this boom is suggested by a comparison of total area of housing starts to population increment, their ratio being 74 square meters per additional person over the 1974-80 period, compared to 57 square meters in Israel. As is indicated in the empirical analysis undertaken below, interactions between Israel and the territories in the economic sphere, coupled with changes in Palestinian economic well-being, appear important determinants of that population's propensity to migrate.

\section{Model Specification}

Reference to the economics literature suggests several approaches purporting to explain migration. One involves application of the neoclassical theory of investment, as has appeared largely in the works of the Chicago School (Schultz, 1961; Sjaastad, 1962), and suggests that a difference in the discounted economic return between two places may precipitate migration, provided the total costs of migration are sufficiently small. Other approaches include that of the Harvard 
School and in particular the work of Kuznets et al. (1957, 1960, 1964), which emphasizes selectivity of migrant stock; and those relevant 'push' and 'pull' factors noted in the early works of Ravenstein (1985, 1889) and Redford (1926). The Kuznets theory emphasizes the importance of human capital characteristics in describing migratory phenomena, suggesting migrants come from select groups endowed with a higher propensity to migrate. The Ravenstein approach stresses other factors than economic, including political and social change, agrarian reform, attraction of the destination region and the like, in an explanation of population flows.

This study tests hypotheses consistent with those economic and political economic theories of migration. Evaluation of the Kuznets hypothesis is constrained due to lack of adequate human capital descriptors. Further, the limited available data on Palestinian migration characterizes that flow in net terms. The net emigration rate then comprises the dependent variable of the model and behavioral motivation for its application may be supplied by turning first to structural equations of gross population flows.

Following Walsh (1974), Greenwood (1975), Fields (1982) and others, structural equations of population migration are written in terms of origin and destination region economic opportunity. Here

$$
\begin{aligned}
& M_{i j t}=\alpha+\beta_{1} U_{i t}^{e}+\beta_{2} U_{j t}^{e} \\
& M_{j i t}=\alpha^{\prime}+\beta_{1}^{\prime} U_{i t}^{e}+\beta_{2}^{\prime} U_{j t}^{e} \\
& N M_{i j t}=\left(\alpha-\alpha^{\prime}\right)+\left(\beta_{1}-\beta_{1}^{\prime}\right) U_{i t}^{e}+\left(\beta_{2}-\beta_{2}^{\prime}\right) U_{j t}^{e}
\end{aligned}
$$


where $M_{i j t}$ is gross migration from area $i$ to area $j$ in period $t$; $N M_{i j t}$ is net emigration from $i$ to $j$; and $U_{i t}^{e}$ is a measure of expected net return on employment that would accrue to a typical potential migrant in location i.

It is assumed that improvements in employment opportunity at the point of origin serve to diminish emigration, whereas similar improvements in the destination region have the opposite effect. As such, model hypotheses include $\beta_{1}, \beta_{2}^{\prime}<0$ and $\beta_{2}, \beta_{1}^{\prime}>0$. Empirical application of the reduced form Equation 3 tests the hypotheses that $\left(\beta_{1}-\beta_{1}^{\prime}\right)<0$ and $\left(\beta_{2}-\beta_{2}^{\prime}\right)>0$.

Various transformations of the above equation have been evaluated in the literature. One involves the so called 'symmetric' model, which holds that the 'push' of unfavorable employment conditions in the area of origin is equivalent in impact to the 'pull' of favorable employment conditions at a possible destination. This hypothesis may be tested by rewriting Equation 3 in differences form, such that

$$
N M_{i j t}=\left(\alpha_{0}-\alpha_{0}^{\prime}\right)+\left(\beta_{0}-\beta_{0}^{\prime}\right)\left(U_{i}-U_{j}\right)_{t}^{e}
$$

In this case, the constraint is simply imposed on Equation 3 that $\left(\beta_{1}-\beta_{1}^{\prime}\right)=-\left(\beta_{2}-\beta_{2}^{\prime}\right)$. It is then hypothesized that $\left(\beta_{0}-\beta_{0}^{\prime}\right)<0$.

Note that the above formulations assume that the same absolute change in $U_{i}$ or $U_{j}$ has the same impact on $M_{i j t}$, regardless of the magnitude of $U_{i}$ or $U_{j}$. One obvious alternative to that assumption is to specify the structural 
equations in terms of migrant expectations concerning the ratio of $U_{i}$ to $U_{j}$. The reduced form equation in this case becomes

$$
N M_{i j t}=\left(\lambda-\lambda^{\prime}\right)+\left(\rho-\rho^{\prime}\right)\left(U_{i} / U_{j}\right)_{t}^{e}
$$

In the analysis undertaken below, various asymmetric (levels), symmetric (differentials) and ratio formulations of the $U$ variables are tested and evaluated.

A further objective of this study is to analyze the relevance of various expectations formulations of the decision to migrate. In that the potential migrant's decision often involves a relatively long time-frame, time-series data may be applied to evaluate the structure of expectations. Yet few studies explore the formulation of expectations in this context (see walsh, 1974; Wilkinson, 1970) due, perhaps, to the predominance of inter-regional and inter-metropolitan data sets. This study tests various typical expectations formulations regarding $U \mathrm{e}$, including those associated with static, extrapolative and adaptive models.

As regards the former, a simple static expectations model assumes that the situation prevailing in the current period will continue to exist in the next. To test this hypothesis, the model is written as

$$
U_{t}^{e}=U_{t-1}
$$

where $U_{t-1}$ is the actual value of $U$ in period $t-1$.

A slightly looser version of this hypothesis involves extrapolative expectations, in which the expected value of the decision variable reflects the immediate past value plus or 
minus some correction based upon the change in this variable over the past few periods. In the extrapolative expectations model tested below,

$$
U_{t}^{e}=U_{t-1}+\gamma\left(U_{t-1}-U_{t-2}\right)
$$

where $\gamma$ reflects the coefficient of adjustment in the potential migrant's expectations based upon the change in past values of $U . \quad \gamma>0$ implies that the direction of change in the decision variable is expected to continue, whereas $\gamma<0$ indicates past trends are expected to reverse themselves.

Finally, the adaptive expectations model may be formulated as

$$
U_{t}^{e}=U_{t-1}^{e}+\theta\left(U_{t-1}-U_{t-1}^{e}\right) \quad|\theta|<1
$$

This specification of the potential migrant's expectations assumes that in each period the previous period's level of $U^{e}$ is corrected by some fraction, $\theta$, of the discrepancy between that period's forecasted and actual level of the decision variable. Algebraic transformation of this difference equation yields the general expression

$$
U_{t}^{e}=\theta \sum_{s=0}^{\infty}(1-\theta)^{s} U_{t-s-1}+c(1-\theta)^{t}
$$

where $c$ is a constant. Upon substituting $\lambda=1-\theta$, and assuming $c=0$, which is a necessary condition for the path of $U_{t}^{e}$ to be bounded for every $t$ : 


$$
U_{t}^{e}=(1-\lambda) \sum_{s=0}^{\infty} \lambda^{s} U_{t-s-1}
$$

Where $|\lambda|<1$, the term $\sum_{s=0}^{\infty} \lambda^{s}$ reduces to a geometrically declining weighted average equal to $1 /(1-\lambda)$. As $s$ well known, the adaptive expectations formulation may be expressed as a weighted average of past values of the decision variable over the relevant time horizon.

The expectations hypotheses embodied in Equations 6, 7 and 8 may then be substituted into the net migration equation for $U_{t}^{e}$ and the final form of the estimating equation derived. For example, in the 'symmetric' form of the model (Equation 4), the estimating equations can be written

$$
\begin{aligned}
& N M_{i t}=\alpha_{0}+\alpha_{1}\left(U_{i}-U_{j}\right)_{t}+\alpha_{2} \mathbf{E}_{t} \\
& N M_{i t}=\delta_{0}+\delta_{1}(1+\lambda)\left(U_{i}-U_{j}\right)_{t-1}+\delta_{1} \gamma\left(U_{i}-U_{j}\right)_{t-2}+\delta_{2} \mathbf{E}_{t} \\
& N M_{i t}=\mu_{0}+\mu_{1} \theta\left(U_{i}-U_{j}\right)_{t-1}+\mu_{1} \theta(1-\theta)\left(U_{i}-U_{j}\right)_{t-2}+\mu_{2} \mathbf{E}_{t}
\end{aligned}
$$

for the static, extrapolative and adaptive expectations structures, respectively. Here $\mathbf{E}$ represents a vector of additional economic and political economic variables which, while not explicitly characterized in the expectations framework, are hypothesized to impinge on the potential migrant's decision-making calculus. Estimating equations can similarly be written for the symmetric (Equation 3 ) and ratio (Equation 5) forms of the model. Given estimation of the extrapolative and adaptive expectation models, application of 
asymptotic distribution theory enables subsequent calculations regarding both the magnitude and significance of $\delta, \gamma, \mu$, and $\theta$. It is to empirical testing of the model that we now turn.

\section{Model Evaluation}

Variables and hypotheses

This study utilizes origin and destination region unemployment rates as empirical measures of $U$. The choice of variables is consistent with extensive analyses of unemployment rates in the migration literature (see Gallaway et al., 1967; Wadycki, 1974; Walsh, 1974). It is suggested that the unemployment rate in the destination region serves as a good proxy for the probability that the potential migrant will find employment there and thus realize a positive return on migration. Similarly, unemployment rate in the origin region proxies employment opportunity in that area, such that increases in that rate should be reflected in increased emigration.

Evidence cited above concerning widespread participation of the territories' labor force in the Israeli economy suggests the relevance of unemployment rate there (UEIS) as an indicator of origin region employment opportunity. Unemployment rates in the West Bank (UEWB) and Gaza (UEG) were also tested as measures of relevant origin region effects. Evaluation of similar destination region effects is constrained, however, due to lack of appropriate data. As noted above, there exists no comprehensive information regarding the destinations of Palestinian emigrants from the West Bank and Gaza. During the period in question, west Bank residents did not require work 
permits to enter Jordan and their migration is not recorded in official statistics there. Finally, none of the Arab states distinguish in published statistics between Palestinians and Jordanians, making it nearly impossible to identify Palestinian manpower in the Persian Gulf. These constraints in available data coupled with the importance of the USA as a secondary destination region prompted the utilization of the US unemployment rate (UEUS) to proxy foreign employment opportunity. Further transformations of the expectational variable include DUE, defined as the difference between the US and Israel employment rates and UER, which comprises the ratio of the former to the latter. As described above, it is expected that increases in DUE and UER be reflected in diminished Palestinian emigration, ceteris paribus.

In addition to evaluation of the employment variable, this study tests the effects of various other economic and political economic factors in an explanation of Palestinian emigration from the territories. The latter include variables proxying changes in origin region consumption patterns (CONCHG), housing opportunities (BLDSTARTS), and external transfer receipt (RTRAN), as well as an indicator of Israeli settlement activity (SETL) there. Variable definitions and sources are found in the Appendix; variable hypotheses are detailed below.

The consumption change index represents, in part, fluctuations in origin region standard of living. As indicated above, substantial improvements in population consumption patterns occurred in the territories over the period of Israeli rule. These private consumption gains reflect increased opportunity costs of emigration, and are expected to be inversely related to the dependent variable, ceteris paribus.

As described above, the Territories experienced a substantial boom in residential construction during the mid-1970s. Finance 
of housing construction was sometimes undertaken by external Arab sources as well, a policy implemented to diminish local population propensity to migrate. The effect of improved local housing opportunities on population migration is proxied by the construction rate variable, and is hypothesized to be negative.

Private transfers to the Territories primarily reflect the remittances of major external philanthropic organizations. This funding is typically directed to social, health and educational institutions and thus suggests improved human service facilities in the origin region. As such, receipt of those funds is expected to diminish the rate of emigration.

Israeli settlement of the Territories may have a variety of political and economic effects on Palestinian propensity to migrate. On the one hand, increased Israeli presence in the territories, political conflict and uncertainty regarding the eventual status of this region may result in accelerated Palestinian emigration. These same elements, however, may increase the resolve of nationalist Palestinians to remain. Finally, in the economic sphere, intensified Israeli settlement of the territories provides employment and commercial spillovers for local residents, thereby diminishing migration propensities. A priori, the relative strength of these various effects remains unclear .

Finally, there exists significant economic and ecological differences between the West Bank and Gaza Strip. The West Bank contains relatively developed agricultural and commercial sectors and a substantially more affluent and educated populace. In addition, west Bank inhabitants enjoy increased migratory opportunities via the Jordan River bridges, given the familial, legal and economic ties which bind the East and West Banks. Separate analyses of the West Bank and Gaza Strip samples are 
expected to yield significant differences in underlying migratory phenomena. The results of these analyses are reported.

Table 1. Net emigration rate, West Bank, 1968-81: estimated (OLS) regression coefficients ( $t$-ratios in parentheses), static expectations models

\begin{tabular}{|c|c|c|c|c|}
\hline \multirow{2}{*}{$\begin{array}{l}\text { Explanatory } \\
\text { Variable }\end{array}$} & \multicolumn{4}{|c|}{ Equation } \\
\hline & 1 & 2 & 3 & 4 \\
\hline CONCHG & $\begin{array}{l}-0.62 \\
(2.42)\end{array}$ & $\begin{array}{l}-0.66 \\
(2.59)\end{array}$ & $\begin{array}{l}-0.58 \\
(1.68)\end{array}$ & $\begin{array}{l}-0.59 \\
(1.88)\end{array}$ \\
\hline BLDSTART & $\begin{array}{l}-0.011 \\
(2.24)\end{array}$ & $\begin{array}{l}-0.013 \\
(2.76)\end{array}$ & $\begin{array}{l}-0.02 \\
(2.65)\end{array}$ & \\
\hline RTRAN & $\begin{array}{l}-0.97 \\
(1.88)\end{array}$ & $\begin{array}{l}-1.08 \\
(2.12)\end{array}$ & $\begin{array}{l}-1.01 \\
(1.42)\end{array}$ & $\begin{array}{l}-1.07 \\
(1.70)\end{array}$ \\
\hline SETL & $\begin{array}{l}-0.52 \\
(1.70)\end{array}$ & $\begin{array}{l}-0.65 \\
(2.26)\end{array}$ & $\begin{array}{l}-0.75 \\
(1.89)\end{array}$ & $\begin{array}{l}-0.50 \\
(1.56)\end{array}$ \\
\hline DUE & - & $\begin{array}{l}-4.97 \\
(5.01)\end{array}$ & - & - \\
\hline UEUS & $\begin{array}{l}-5.41 \\
(5.04)\end{array}$ & - & - & $\begin{array}{l}-5.20 \\
(4.45)\end{array}$ \\
\hline UEIS & $\begin{array}{c}3.59 \\
(2.16)\end{array}$ & - & - & - \\
\hline UEWB & - & - & - & $\begin{array}{c}3.64 \\
(1.85)\end{array}$ \\
\hline UER & - & - & $\begin{array}{l}-13.03 \\
(3.24)\end{array}$ & - \\
\hline Constant & $\begin{array}{l}30.37 \\
(3.47)\end{array}$ & $\begin{array}{l}25.37 \\
(3.46)\end{array}$ & $\begin{array}{l}36.60 \\
(2.73)\end{array}$ & $\begin{array}{l}30.85 \\
(2.97)\end{array}$ \\
\hline$R^{2}$ & 0.831 & 0.831 & 0.690 & 0.760 \\
\hline$D-W$ & 2.79 & 2.56 & 2.10 & 2.27 \\
\hline
\end{tabular}


Estimation results

The results of applying OLS regression techniques to static expectations models (Equation 6) are presented in Tables I and 2 for the West Bank and Gaza Strip, respectively. Each table displays findings associated with the asymmetric (Equation 3), symmetric (Equation 4), and ratio (Equation 5) specifications. The regression coefficients are shown, with t-ratios in parentheses.

The static expectations model performs well for the West Bank sample. In this case, all regression coefficients are consistent with hypotheses and are statistically significant at the $90 \%$ level or above. Comparison of Equations 1, 2 and 3 indicates that this model is of similarly good fit in either the asymmetric or symmetric forms of the expectations variables, but performs somewhat less well in ratio form. In the case of Equation I, for instance, the recovery of Western economies from recession early in the decade and in particular each percentage point fall in the US rate of unemployment should increase Palestinian emigration rate by 5.4 or 3800 persons. The opposite holds true in the context of the Israeli economy in that emigration rate increases by 3.6 or 2500 persons with each percentage point rise in the domestic unemployment rate.

These findings further suggest that increases in construction rate and real, per capita consumption expenditures, reflecting improved origin region consumption and housing conditions, serve to diminish the rate of Palestinian emigration. A similar outcome is detected in the case of increased private remittances from abroad. Finally, results suggest that intensified Israeli 
Table 2. Net emigration rate, Gaza Strip, 1968-81: estimated (OLS) regression coefficient ( $t$-ratios in parentheses), static expectations models

\begin{tabular}{|c|c|c|c|c|}
\hline \multirow{2}{*}{$\begin{array}{l}\text { Explanatory } \\
\text { Variable }\end{array}$} & \multicolumn{4}{|c|}{ Equation } \\
\hline & 5 & 6 & 7 & 8 \\
\hline CONCHG & $\begin{array}{l}-0.42 \\
(2.14)\end{array}$ & $\begin{array}{l}-0.38 \\
(1.87)\end{array}$ & $\begin{array}{l}-0.37 \\
(1.80)\end{array}$ & $\begin{array}{l}-0.29 \\
(1.70)\end{array}$ \\
\hline BLDSTART & $\begin{array}{l}-0.027 \\
(2.05)\end{array}$ & $\begin{array}{l}-0.028 \\
(2.00)\end{array}$ & $\begin{array}{l}-0.03 \\
(2.10)\end{array}$ & $\begin{array}{l}-0.04 \\
(3.10)\end{array}$ \\
\hline RTRAN & $\begin{array}{c}0.45 \\
(0.41)\end{array}$ & $\begin{array}{l}-0.67 \\
(0.87)\end{array}$ & $\begin{array}{l}-0.48 \\
(0.54)\end{array}$ & $\begin{array}{l}-0.5 \odot \\
(0.79)\end{array}$ \\
\hline SETL & $\begin{array}{c}0.51 \\
(1.54)\end{array}$ & $\begin{array}{c}0.42 \\
(1.22)\end{array}$ & $\begin{array}{c}0.41 \\
(1.20)\end{array}$ & $\begin{array}{c}0.35 \\
(1.25)\end{array}$ \\
\hline DUE & - & $\begin{array}{l}-0.31 \\
(0.29)\end{array}$ & - & $\begin{array}{l}-1.90 \\
(1.65)\end{array}$ \\
\hline UEUS & $\begin{array}{l}-0.69 \\
(0.65)\end{array}$ & - & - & - \\
\hline UEIS & $\begin{array}{l}-3.12 \\
(1.14)\end{array}$ & - & - & - \\
\hline UEG & - & - & - & $\begin{array}{l}-1.60 \\
(2.10)\end{array}$ \\
\hline UER & - & - & $\begin{array}{c}0.29 \\
(0.08)\end{array}$ & - \\
\hline Constant & $\begin{array}{c}9.55 \\
(1.05)\end{array}$ & $\begin{array}{c}7.04 \\
(0.75)\end{array}$ & $\begin{array}{c}4.20 \\
(0.31)\end{array}$ & $\begin{array}{l}14.09 \\
(1.70)\end{array}$ \\
\hline$R^{2}$ & 0.261 & 0.174 & 0.160 & 0.450 \\
\hline$D-W$ & 2.01 & 1.60 & 1.72 & 2.30 \\
\hline
\end{tabular}


settlement of the West Bank is reflected in diminished Palestinian emigration. While the relative weight of various political and economic effects associated with this outcome remain unclear, this result in part reflects economic spillovers associated with Israeli immigration and settlement.

As is indicated by Table 2, the static expectations model is of limited applicability to the Gaza Strip sample. While the construction rate and consumption estimates are of a similar order of magnitude to those of the West Bank and statistically significant, other results are inconsistent with model hypotheses and/or lack an appropriate degree of significance. The latter situation characterizes the various formulations of the expectations variables. Interestingly enough, increases in origin region unemployment rates lead to diminished emigration. Such a result may stem from the relatively depressed economic status of the Gaza population and, in that regard, the existence of a wealth barrier to migration. Further, as indicated earlier, the Gaza population enjoys none of the legal advantages available to those from the West Bank concerning short-term access to Jordanian labor markets. 4

Results of the extrapolative and adaptive models are less satisfactory than those obtained with the static expectations formulations and hence are not displayed. 5 Note, however, that

\footnotetext{
${ }^{4}$ While it is common to limit migration models to a single-equation approach, certain assumptions of the classical least squares regression model may be violated, as the regressors may not be exogenous to the economic process which determined migration. In the case at hand, it appears reasonable to inquire as to whether migration from the territories impacts on employment rates there. If so, the model should be estimated as a two-equation simultaneous system. It should be noted, however, that this issue pertains only to those equations which utilized territories' unemployment rates, rather than those in Israel, to proxy origin region employment conditions. Simultaneous equations bias was considered more unlikely in that emigrants include non-labor force participants and equal only $6 \%$ of total labor force. In investigating this issue, a two-equation system of the type described above was estimated using two-stage least squares techniques. Results of this analysis show the estimated coefficient of net emigration rate in the employment equation to be approximately zero in value and statistically insignificant. On this basis, only results of the single-equation migration model are presented.

${ }^{5}$ These results are available from the authors upon request.
} 
in the case of the West Bank, the extrapolative expectations coefficient of adjustment, $y$, is both negative and significant. This result implies that changes in employment opportunity are expected to reverse themselves, as is consistent with actual variation in the expectations indices. As regards the adaptive expectations models, the estimated coefficient of adjustment 0 for the West Bank lacks a reasonable level of significance and varies in both magnitude and sign between the symmetric and ratio formulations.

\section{Conclusions}

This study had undertaken to analyze the structure and determinants of Palestinian migration from the West Bank and Gaza over the post-1967 period of Israeli rule. The migration totaled about 96000 during the 1970s, equivalent to almost half the natural increase in population. The factors underlying this exodus are viewed with considerable political import, given the competition, as well as controversy, regarding development and control of this region.

Results of the analysis indicate the relevance of particular Palestinian-Israeli interactions, including those associated with traditional economic variables in an explanation of Palestinian migration. In that regard, the importance of employment opportunity and labor market conditions in the origin and destination regions is illustrated. Improved local housing and consumption opportunities result in diminished west Bank migration, as do the remittances provided by international philanthropic organizations. Also, whether due to local commercial and employment spillovers or nationalist sentiment, 
intensified Israeli settlement of the West Bank similarly serves to diminish Palestinian emigration from this region.

These findings lend tentative support to certain conclusions regarding model specification and the structure of expectations. A primary concern of this research was whether variation in migration rates might be explained on the basis of adaptive or extrapolative expectations concerning future employment opportunity, as distinct from a simple index of current conditions. The former expectations models perform appreciably less well than a simple static expectations formulation, however, indicating the relevance of current employment conditions to west Bank migrants. The short-run decision horizon of Palestinian migrants concurs with findings regarding diverse migratory groups including analyses of Irish migration to Britain (Walsh, 1974) and emigration from the United Kingdom to the USA (Gallaway and Vedder, 1971). Finally, despite the theoretical rationale for specification of expectations indices in ratio form, results of the static expectations model favor the use of either the asymmetric (levels) or symmetric (differences) form of the unemployment variables.

In conclusion, this study has certain policy implications. Transfers from external Arab and international sources have worked to improve local conditions and diminish Palestinian migratory propensities, as is consistent with the political aims of that funding. From the perspective of Israelis concerned With the West Bank 'demographic imbalance', however, there exists conflict between development of a Palestinian labor market in Israel and emigration of that group. Finally, from the Palestinian point of view, the failure to channel resources into manufacturing investment and infrastructure rather than consumption is of central concern. In the absence of an indigenous productive base, Palestinian labor supply remains 
highly elastic, reflecting cyclical fluctuations in the Israeli economy as well as similar developments in the various destination regions. 


\section{Appendix}

$\begin{array}{ll}\text { Definitions of variables in the migration models } \\ \text { NMIG } & \begin{array}{l}\text { Net emigration rate in migrants per } 1000 \\ \text { population }\end{array} \\ \text { CONCHG } & \begin{array}{l}\text { Percentage change over previous year in real, per } \\ \text { capita consumption expenditures }\end{array} \\ \text { RTRAN } & \text { Real, per capita private unilateral transfers to } \\ & \text { the west Bank } \\ \text { SET } & \text { New Israeli settlements in the West Bank } \\ \text { BLDSTART } & \text { Construction starts in the west Bank in square } \\ & \text { meters } \\ \text { UEUS } & \text { Unemployment rate, USA } \\ \text { UEIS } & \text { Unemployment rate, Israel } \\ \text { UEWB } & \text { Unemployment rate, West Bank } \\ \text { UEG } & \text { Unemployment rate, Gaza Strip } \\ \text { DUE } & \text { Difference between the US and Israeli } \\ \text { UER } & \text { unemployment rates } \\ \text { UER2 } & \text { Ratio of the US to Israeli unemployment rates } \\ & \text { Ratio of the US to West Bank unemployment rates }\end{array}$

\section{Sources}

Israel Central Bureau of Statistics, Statistical Abstract of Israel.

US Bureau of the Census, Statistical Abstract of the United States.

Benvenisti, M., Interim Report No. 1, West Bank and Gaza Data Base Project, Jerusalem (1982). 


\section{References}

Ben Shahar, H., Bergles, E., Mundlak, Y. and Sadan, E. (1971)

Economic Structure and Development Prospects of the West Bank and Gaza Strip, Rand Corporation, R-839-FF, Santa Monica, CA. Benvenisti, M. (1982) Interim Report No. 1, The West Bank and Gaza Data Base Project, Jerusalem.

Fields, G. (1982) Place-to-place migration in Colombia, Economic Development and Cultural Change, $0 \odot, 539-58$.

Gallaway, L., Gilbert, R. and Smith, P. (1967) The economics of labor mobility: an empirical analysis, western Economic Journal, 6, 211-23.

Gallaway, L. and Vedder, R. (1971) Emigration from the United Kingdom to the United States: 1860-1913, Journal of Economic History, 31, 885-97.

Greenwood, M. (1975) Research on internal migration in the United States: a survey, Journal of Economic Literature, 13, 397-404 .

Israel Central Bureau of Statistics (1982) Statistical Abstract of Israel.

Kuznets, S., Thomas, D. (1957, 1960, 1964) Population

Redistribution and Economic Growth - United States, 18701950, 3 vols, American Philosophical Society, Philadelphia. Meron, R. (1983) Economic development in Judea-Samaria and the Gaza district, Research Department, Bank of Israel, Jerusalem, May.

Nisan, M. (1982) The Palestinian features of Jordan, in Judea, Samaria, and Gaza: Views of the Present and Future, (Ed.) D. Elezar, American Enterprise Institute, Studies in Foreign Policy, Washington, DC.

Ravenstein, E. (1885) The laws of migration, Journal of the Royal Statistical Society, 48. 
Ravenstein, E. (1889) The laws of migration, Journal of the Royal Statistical Society, 52.

Redford, A. (1926) Labor Migration in England, University Press, Manchester .

Sandler, S. and Frisch, H. (1982) The political economy of the Administered Territories, in Judea, Samaria, and Gaza: Views of the Present and Future, (Ed.) D. Elezar, American Enterprise Institute, Studies in Foreign Policy, Washington, DC.

Schultz, T. W. (1961) Investment in human capital, American Economic Review, 51, pp. 1-17.

Sjaastad, L. A. (1962) The costs and returns of human migration, Journal of Political Economy, Supplement, 70,80-93.

Wadycki, A. (1974) A note on opportunity costs and migration analysis. Annals of Regional Science, 8, 109-17.

Walsh, B. (1974) Expectations, information, and human migration: specifying an econometric model of Irish migration to Britain, Journal of Regional Science, 14, 107-20.

Wilkinson, M. (1970) European migration to the United States, an econometric analysis of aggregate labor supply and demand, Review of Economics and Statistics, 52,272-9. 